\title{
Effect of Dietary Supplement, Base Mix, and/or Soybean Meal on Growing Pig Performance
}

\author{
Samorn Sreng1*, Sath Keo², J. M. DeRouchey ${ }^{3}$, M. D. Tokach ${ }^{3}$, Bunna Chea², Kroesna Kang², \\ Lyda Hok ${ }^{4,5}$, J. L. Vipham ${ }^{3}$ \\ ${ }^{1}$ Faculty of Animal Science, Royal University of Agriculture, Phnom Penh, Cambodia \\ ${ }^{2}$ Faculty of Veterinary Medicine, Royal University of Agriculture, Phnom Penh, Cambodia \\ ${ }^{3}$ Department of Animal Sciences and Industry, Kansas State University, Manhattan, USA \\ ${ }^{4}$ Faculty of Agronomy, Royal University of Agriculture, Phnom Penh, Cambodia \\ ${ }^{5}$ Center of Excellence on Sustainable Agricultural Intensification and Nutrition, Royal University of Agriculture, Phnom Penh, \\ Cambodia \\ Email: *samonsreng@gmail.com
}

How to cite this paper: Sreng, S., Keo, S. DeRouchey, J.M., Tokach, M.D., Chea, B., Kang, K., Hok, L. and Vipham, J.L. (2020) Effect of Dietary Supplement, Base Mix, and/or Soybean Meal on Growing Pig Performance. Open Journal of Animal Sciences, $10,535-544$.

https://doi.org/10.4236/ojas.2020.103034

Received: June 14, 2020

Accepted: July 13, 2020

Published: July 16, 2020

Copyright (c) 2020 by author(s) and Scientific Research Publishing Inc. This work is licensed under the Creative Commons Attribution International License (CC BY 4.0)

http://creativecommons.org/licenses/by/4.0/

\begin{abstract}
A total of 60 crossbred pigs (Yorkshire $\times$ Duroc, initially $56.5 \mathrm{~kg}$ ) were used in a 42-day trial to evaluate the effect of replacing a commercial high protein supplement with soybean meal and/or a base mix in rice bran-based diets on pig growth performance. Pigs were allotted to pens by body weight and pens were randomly assigned to dietary treatments in completely randomized design. There were 4 dietary treatments with 3 or 4 replicate pens per treatment and 4 pigs per pen. Dietary treatments were: 1) $80 \%$ rice bran with $20 \%$ high protein supplement (RBS20), 2) $95 \%$ rice bran with $5 \%$ high protein supplement (RBS5), 3) $97.5 \%$ rice bran with $2.5 \%$ base mix (RBB2.5), and 4) $92.5 \%$ rice bran with $5 \%$ soybean meal and $2.5 \%$ base mix (RBSBB). The base mix included vitamins, macro and trace minerals, L-Lysine, L-Threonine, and DL-Methionine. Overall ( 0 to 42$)$ average daily gain was greater $(P<0.001)$ for pigs fed RBSBB and RBS20 diets than pigs fed the RBS5 or RBB2.5 diets. Pigs fed the RBS5 diet had reduced $(P<0.004)$ average daily feed intake compared to all other treatments. Similarly, feed efficiency (feed/gain) was improved $(P<0.004)$ for pigs fed RBSBB and RBS20 diets compared with pigs fed RBS5 or RBB2.5. For economics, income over feed cost was the greatest $(P<0.01)$ for the diet containing soybean meal and base mix compared to pigs fed the RBS20 diet, SBS5, and RBB2.5. In conclusion, feeding pigs a rice bran diet with base mix and soybean meal had similar growth performance and increased economic return compared to feeding a rice bran diet with high protein supplement. Use of soybean meal and base mix provides an opportunity for increased economic return for pig farmers.
\end{abstract}


Keywords

Base Mix, Growing Pigs, Growth Performance, Rice Bran, Soybean Meal

\section{Introduction}

Feed quality is often a major limiting factor for most smallholder pig farmers in Cambodia. In fact, feed costs contribute up to $60 \%$ to $70 \%$ of the total cost of pig production in the country [1]. Animal feeds are commonly imported from surrounding countries (i.e. Thailand or Vietnam); which contributes to the high cost of feed within the country [2]. With this, smallholder farmers often cannot afford complete feeds. Therefore, many smallholder farmers utilize local feed materials and/or left-over food as feed. Commonly, Cambodia farmers will purchase a low-cost ingredient, such as rice bran, to feed to pigs. Rice bran contains $8.7 \%$ to $14 \%$ protein [3] [4] [5], $11.9 \%$ to $21.5 \%$ crude fiber [5] [6] [7], and 13 to $18.8 \%$ fat [4] [5]. The quality of rice bran can vary, but generally it is a medium energy and protein source with basal levels of vitamins and minerals [8] [9]. Unfortunately, rice bran is insufficient in protein and/or vitamins and minerals to meet the daily nutrient needs of swine, but many farmers do not supplement diets with these essential nutrients. Therefore, rice bran must be supplemented with a source of amino acids, vitamins, and minerals to meet pig's requirements.

While nutrient requirements of amino acids, macro and micro minerals and vitamins for growing pig performance have been reported [10], pigs in developing counties are not often fed these levels. Vitamins and minerals are often included in high protein commercial supplements, but these products are expensive and the concentration of amino acids, vitamins, and minerals included in them is often unknown. A base mix or premix is often used to provide vitamins and minerals, but does not contain adequate protein to be supplemented alone with rice bran. However, some small-scale farmers use this approach in an attempt to provide some nutrients without knowledge of the impact on pig performance. Soybean meal is a consistent and high-quality protein source has been used across the world as a protein source for pigs. Soybean meal is higher in concentration of amino acids such as lysine, which is the first limiting amino acid in the most grain-based diets [11]. The objective of this current study was to evaluate the effect of replacing a high protein supplement with soybean meal and/or base mix in rice bran diets on growing-finishing pigs' performance and economic return.

\section{Material and Methods}

\subsection{The Site of Study and Climate Condition}

The experiment was conducted in a commercial pig barn facility in the district of S'ang, Kandal province, Cambodia. The trial was conducted in the rainy season (May to October) with the average daily temperature of $29^{\circ} \mathrm{C}$ and $80 \%$ in hu- 
midity. A thermometer sensor measured the daily temperature and humidity inside the pig barn in which the minimum and maximum temperature of $23^{\circ} \mathrm{C}$ and $35^{\circ} \mathrm{C}$, respectively. Relative humidity ranged from $70 \%$ to $90 \%$ during the experiment.

\subsection{Pigs and Experimental Design}

A total of 60 crossbred pigs (Yorkshire $\times$ Duroc) were purchased from a large commercial farm with an initial body weight of $56.5 \mathrm{~kg}$ and used in a 42-day experiment. Pigs were housed in $2 \times 3 \mathrm{~m}$ pens with a nipple drinker to supply ad libitum access to fresh water. Pigs were allotted to pens by body weight and pens were randomly assigned to dietary treatments in completely randomized design. There were 4 dietary treatments with 3 or 4 replicate pens per treatment and 4 pigs/pen. Dietary treatments were: 1) $80 \%$ rice bran with $20 \%$ high protein supplement (RBS20), 2) $95 \%$ rice bran with 5\% high protein supplement (RBS5), 3) 97.5\% rice bran with $2.5 \%$ base mix (RBB2.5), and 4) $92.5 \%$ rice bran with $5 \%$ soybean meal and $2.5 \%$ base mix (RBSBB). The $20 \%$ inclusion rate for the high protein supplement was according to the manufacturer recommendations. The second treatment included the high protein supplement at a reduced rate $(5 \%)$ to mimic a typical approach of local farmers where the supplement is used at a reduced inclusion rate to lower cost. The third treatment was used to determine the benefit of vitamin and mineral addition to rice bran without protein supplementation. For the last treatment, $5 \%$ soybean meal was added to the third treatment as an amino acid source to meet all requirements of the pigs.

\subsection{Diets and Feeding}

Feed ingredients, including rice bran, soybean meal, and supplement (Deheus 3401) were purchased from local feed supplier in Kandal province, Cambodia. The base mix was manufactured by Provimi Company, in Vietnam. The experimental diets are shown in Table 1. Each experimental diet was thoroughly mixed every two days and stored in a clean bag (total $50 \mathrm{~kg}$ of feed in each bag) until feeding. Feed was offered ad libitum to pigs and provide three times per day at 07:00, 12:00, and 18:00. Every morning prior to the feeding, the trough in each pen was cleaned and new feed was added. The collected residual feed from each pen was weighed using an electronic scale and recorded.

\subsection{Data Collection}

Feed offered and residual of each pen were recorded daily and pigs were individually weighed and recorded on $\mathrm{d} 0,21$, and 42 day of the study to calculate average daily gain (ADG), average daily feed intake (ADFI) and feed efficiency $(\mathrm{F} / \mathrm{G})$.

\subsection{Sample Collection and Analytical Analysis}

Sub-samples of rice bran, soybean meal, supplement and complete feed were 
Table 1. Composition of basal diet used in the experiment (as-fed basis).

\begin{tabular}{ccccc}
\hline \multirow{2}{*}{ Items,\% } & \multicolumn{4}{c}{ Experimental Diet } \\
\cline { 2 - 5 } & RBS20 & RBS5 & RBB2.5 & RBSBB \\
\hline Rice bran & 80 & 95 & 97.5 & 92.5 \\
Supplement & 20 & 5 & - & - \\
Soybean meal & - & - & - & 5 \\
Base mix ${ }^{\mathrm{a}}$ & - & - & 2.5 & 2.5 \\
Total (\%) & 100 & 100 & 100 & 100 \\
Nutrients analysis (DM basis) & & & & \\
Dry matter, \% & 90.07 & 89.07 & 89.50 & 89.38 \\
Crude protein, \% & 19.00 & 13.54 & 12.17 & 13.62 \\
Ether extract, \% & 9.78 & 8.68 & 10.34 & 10.34 \\
Ash, \% & 10.61 & 9.08 & 10.87 & 10.04 \\
Crude fiber, \% & 11.00 & 11.84 & 11.61 & 10.42 \\
Acid detergent fiber, \% & 15.61 & 17.03 & 20.63 & 15.09 \\
Neutral detergent fiber, \% & 24.31 & 22.88 & 23.40 & 21.08 \\
\hline
\end{tabular}

${ }^{a}$ Base mix component per $\mathrm{kg}$ : Lysine $\mathrm{HCl} 3.3 \%$; L-Threonine 3.3\%; DL-Methionine 0.95\%; vitamin A 206,250 IU; vitamin D 42,200 IU; vitamin E 1690 IU; vitamin K 84 mg; vitamin B12 0.85 mg; Niacin 1.240 mg; Pantothenic acid 685 mg; Riboflavin 206 mg; Choline 13,700 mg; Biotin 5.6 mg; Folic acid 56 mg; Pyridoxine $28 \mathrm{mg}$, Copper 415 ppm; Iodine 7.40 ppm; Manganese oxide 825 ppm; Selenium 7.4 ppm; Calcium (min) $20 \%$; digestible phosphorus $5.6 \%$; $\mathrm{NaCl}(\min ) 12.5 \%$.

collected every two weeks for chemical analysis. Chemical analysis was performed at the Chemical Analysis Laboratory, Royal University of Agriculture, Phnom Penh. Experimental diets and feed ingredient samples were collected, subsampled, and analyzed for dry matter by using analysis official method [12]. Ash was ignited in a muffle furnace at $600^{\circ} \mathrm{C}$ during $2 \mathrm{~h}$ due to the description of [12]. Crude protein was determined by Leco FP-528 (LECO Corporation, ISO-9001:2008, USA, 2014), and estimated a calculation of crude protein factor $(\mathrm{N} \times 6.25)$. Ether Extract $(\mathrm{EE})$ was determined by ST243 Soxtec ${ }^{\mathrm{TM}}$ Extraction Unit (Foss Analytical Co., Ltd, China, 2014). Neutral detergent fiber (NDF), acid detergent fiber (ADF) and crude fiber were determined by ANKOM 200i, approved procedure by AOCS (ANKOM Technology, USA).

\subsection{Statistical Analysis}

All data were statistically analyzed by using the software of Statistical Package for the Social Sciences (SPSS) version 18.0 (2015) for Windows. The analytical procedure was processed with one-way of analysis of variance (ANOVA-test) to compare the variable means and determined the statistically significant different of means at the probability level $(P<0.05)$. Duncan test was used to evaluate the difference between means.

\section{Results}

Nutrient analysis of experimental diets is shown in Table 1. The DM content of 
all diets was similar. The CP content was highest for the RBS20 diet indicating the high inclusion of high protein supplement. The RBS5 and RBSBB diets were similar in CP content, but being higher than RBB2.5 diet. The ether extract, crude fiber, ash, and NDF content were similar among diets. The RBB2.5 diet, which contained only rice bran and base mix supplement, had higher ADF content than RBS20, RBS5, and RBSBB diets.

Chemical composition of feed ingredients is shown in Table 2. Rice bran in this experiment had $11.81 \% \mathrm{CP}$ and $12.23 \%$ ether extract on a dry matter basis, but also was high in fiber with almost $11 \%$ crude fiber, $20 \%$ NDF, and $17 \%$ ADF. Soybean meal was $50.5 \% \mathrm{CP}$ and low in fiber and ether extract. The commercial supplement analysis showed that it had a high CP content (46.43\%) and contained high mineral levels ( $18.1 \%$ ash).

From day 0 to 21 , ADG was greater $(P<0.024)$ for pigs fed RBS20 compared to pig fed RBB2.5 and RBS5, with pigs fed RBSBB intermediate (Table 3). There was no difference between treatments for ADFI $(P>0.063)$. Feed efficiency was improved $(P<0.047)$ for pigs fed the diet containing $20 \%$ supplement compared to pigs fed RBB2.5 with those fed RBS5 and RBSBB intermediate. From day 21 to 42 , ADG was higher $(P<0.004)$ for pigs fed diet containing $5 \%$ soybean meal and $2.5 \%$ base mix compared to those fed RBS5 and RBB2.5 with pigs fed RBS20 intermediate. The ADFI was higher $(P<0.002)$ for pigs fed RBS20, RBB2.5, and RBSBB compared with pigs fed the RBS5 diet. However, for F/G, there was no significant differences $(P=0.055)$ between dietary treatments.

Overall (d 0 to 42 ), there was highly significant difference on ADG among diets $(P<0.001)$. Pigs fed the RBSBB and RBS20 diets had greater ADG than pigs fed the RBS5 or RBB2.5 diets. This led to a significant improvement in final body weight $(P<0.010)$ for pigs fed RBSBB and RBS20 compared with pigs fed the RBS5 and RBB2.5 diets. For ADFI there were significant differences between treatments $(P<0.004)$. Pigs fed the RBS5 diet had reduced ADFI compared to other three diets. Similarly, F/G was improved $(P<0.004)$ for pigs fed the diets RBSBB or RBS20 compared with pigs fed RBS5 or RBB2.5.

For economics, all diets were significantly different from each other $(P<$ 0.001 ) for feed cost per pig, with the highest to lowest cost being pigs fed RBS20,

Table 2. Chemical composition of complete feed and morning glory used for the experiment $(\%$ as DM)

\begin{tabular}{cccc}
\hline Items & Rice bran & Soybean meal & Supplement \\
\hline Dry matter & 90.51 & 89.48 & 93.10 \\
Crude protein & 11.81 & 50.45 & 46.43 \\
Crude fiber & 10.96 & 3.46 & 3.67 \\
Ether extract & 12.23 & 1.19 & 4.44 \\
Ash & 8.92 & 7.87 & 18.06 \\
Acid detergent fiber & 16.85 & 6.64 & 6.84 \\
Neutral detergent fiber & 20.65 & 7.32 & 16.68 \\
\hline
\end{tabular}


Table 3. Effect of dietary supplementation, base mix and soybean meal on growing pig performance $^{\mathrm{d}, \mathrm{e}}$.

\begin{tabular}{|c|c|c|c|c|c|c|}
\hline \multirow[t]{2}{*}{ Items } & \multicolumn{2}{|c|}{$\begin{array}{l}\text { Rice bran } 80 \% \text { Rice bran } 95 \% \\
+ \text { Supplement + Supplement }\end{array}$} & \multirow{2}{*}{$\begin{array}{c}\text { Rice bran } \\
97.5 \%+ \\
\text { Base mix } \\
2.5 \%\end{array}$} & \multirow{2}{*}{$\begin{array}{c}\text { Rice bran } \\
92.5 \%+\text { Base } \\
\text { mix } 2.5 \% \\
+ \text { SBM } 5 \%\end{array}$} & \multirow[t]{2}{*}{ SEM } & \multirow[t]{2}{*}{$P<$} \\
\hline & & & & & & \\
\hline \multicolumn{7}{|c|}{ Body weight, kg } \\
\hline D 0 & 56.72 & 56.51 & 56.49 & 56.24 & 0.578 & 0.995 \\
\hline D 21 & $72.92^{\mathrm{a}}$ & $69.67^{\mathrm{b}}$ & $69.55^{\mathrm{b}}$ & $70.36^{\mathrm{b}}$ & 0.462 & 0.028 \\
\hline D 42 & $88.81^{\mathrm{a}}$ & $82.58^{b}$ & $83.91^{\mathrm{b}}$ & $87.94^{\mathrm{a}}$ & 0.789 & 0.010 \\
\hline \multicolumn{7}{|l|}{ Day 0 to 21} \\
\hline ADG, $g$ & $582^{\mathrm{a}}$ & $439^{\mathrm{b}}$ & $451^{\mathrm{b}}$ & $481^{\mathrm{ab}}$ & 18.59 & 0.023 \\
\hline ADFI, g & 2291 & 2082 & 2215 & 2220 & 28.86 & 0.063 \\
\hline $\mathrm{F} / \mathrm{G}$ & $3.95^{\mathrm{b}}$ & $4.81^{\mathrm{ab}}$ & $4.95^{\mathrm{a}}$ & $4.63^{\mathrm{ab}}$ & 0.135 & 0.047 \\
\hline \multicolumn{7}{|l|}{ Day 21 to 42} \\
\hline ADG, $g$ & $757^{\mathrm{ab}}$ & $620^{c}$ & $684^{\mathrm{bc}}$ & $837^{\mathrm{a}}$ & 26.79 & 0.004 \\
\hline ADFI, $g$ & $2,940^{\mathrm{a}}$ & $2,548^{\mathrm{b}}$ & $2.890^{\mathrm{a}}$ & $2,843^{\mathrm{a}}$ & 47.78 & 0.002 \\
\hline $\mathrm{F} / \mathrm{G}$ & 3.92 & 4.13 & 4.26 & 3.41 & 0.128 & 0.055 \\
\hline \multicolumn{7}{|l|}{ Day 0 to 42} \\
\hline ADG, $g$ & $764^{\mathrm{a}}$ & $621^{\mathrm{b}}$ & $653^{\mathrm{b}}$ & $755^{\mathrm{a}}$ & 18.93 & 0.001 \\
\hline ADFI, $g$ & $2615^{\mathrm{a}}$ & $2315^{\mathrm{b}}$ & $2552^{\mathrm{a}}$ & $2531^{\mathrm{a}}$ & 36.26 & 0.004 \\
\hline $\mathrm{F} / \mathrm{G}$ & $3.43^{\mathrm{b}}$ & $3.74^{\mathrm{a}}$ & $3.91^{\mathrm{a}}$ & $3.36^{\mathrm{b}}$ & 0.073 & 0.004 \\
\hline \multicolumn{7}{|c|}{ Economics, USD/pig } \\
\hline Feed cost ${ }^{f}$ & $39.54^{\mathrm{a}}$ & $24.31^{\mathrm{d}}$ & $25.73^{c}$ & $28.71^{\mathrm{b}}$ & 1.50 & 0.001 \\
\hline Gain value ${ }^{g}$ & $68.19^{\mathrm{a}}$ & $55.40^{\mathrm{b}}$ & $58.25^{\mathrm{b}}$ & $67.36^{\mathrm{a}}$ & 1.69 & 0.001 \\
\hline $\mathrm{IOFC}^{\mathrm{h}}$ & $28.65^{\mathrm{b}}$ & $31.09^{b}$ & $32.52^{\mathrm{b}}$ & $38.66^{\mathrm{a}}$ & 1.23 & 0.010 \\
\hline
\end{tabular}

a,b,c Different superscripts are significantly different, $P<0.05$. ${ }^{\mathrm{d} A}$ total of 60 pigs (initially $56.49 \mathrm{~kg}$ body weight) were used in a 42 days studying with 4 pigs per pen and 3 pens of treatment RBS20 and 4 pens each for treatment RBS5, RBB2.5 and RBSBB. ${ }^{e}$ RBS20 = Rice bran $80 \%$ and Supplementation 20\%; RBS5 = Rice bran 95\% and Supplementation 5\%; RBB2.5 = Rice bran 97.5\% and Base mix 2.5\%; RBSBB = Rice bran $92.5 \%$ + Soybean meal $5 \%$ and Base mix $2.5 \%$. ${ }^{\mathrm{f}}$ Assuming diet RBS20 costs $\$ 0.36 / \mathrm{kg}$, diet RBS5 costs $\$ 0.25 / \mathrm{kg}$, diet RBB2.5 costs $\$ 0.24 / \mathrm{kg}$ and diet RBSBB costs $\$ 0.27 / \mathrm{kg}$. ${ }^{\mathrm{g}}$ Assuming a market price of $\$ 2.125 / \mathrm{kg}$.

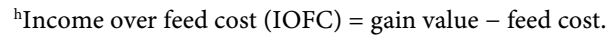

RBSBB, RBB2.5 and RBS5, respectively. Due to the improvements in ADG, pigs fed diets containing base mix and soybean meal and the diet containing $20 \%$ supplement had higher value of gain $(P<0.001)$ than pigs fed the RBS5 or RBB2.5 diets. Finally, for income over feed cost, pigs fed the soybean meal with base mix diet had improved $(P<0.01)$ return compared with pigs fed all other diets.

\section{Discussion}

The composition of rice bran can vary due to the different varieties, origin, and milling methods [4] and due to the concentration of hulls or broken rice that is 
included. The CP content of rice bran used in this experiment (11.81\%) was within the range of $8.70 \%$ to $14.64 \%$ on DM basis of other reports in the literature [3] [4] [6] [7]. The crude fiber content of rice bran in this present study was in agreement with the expected chemical composition [6]. The ash content was similar to the result of Shi [4], but lower than the results of Phiny [6]. The ether extract and NDF content of rice bran in this study were $12.23 \%$ and $20.65 \%$, respectively, which are near the lower end of all values for 17 rice bran samples analyzed by Shi [4]. Additionally, the ADF content in the current study was almost $17 \%$, which is greater than all values of Shi [4] indicating the rice bran was most likely lower in energy than rice bran samples in their study.

Soybean meal (SBM) used in this study contained $50.45 \%$ CP on DM basis and $45.1 \%$ on an as-is basis, which was similar to other reports [5] [13]. Thakur and Hurburgh [14] describe that soybean meal collected from different origins has different nutrient concentrations and varies in quality parameters with $\mathrm{CP}$ concentration ranging from $42.7 \%$ to $51.1 \%$ of DM. The different in meal processing condition including moisture, temperature, and drying time could be resulted in the different quality and its nutrient composition [10] [14]. The value of crude fiber, ether extract, and ash in this present study were $3.46 \%, 1.19 \%$, and $7.87 \%$, which were within the ranges of $2.8 \%$ to $7.7 \%$ for crude fiber, $0.5 \%$ to $2.6 \%$ for ether extract; and $5.3 \%$ to $8.9 \%$ for ash content, respectively [14]. The analytical results indicate that the soybean meal was high quality in this experiment with nutrient values falling near the normal range expected. Analysis of the commercial supplement confirmed that it was a high protein supplement with expected inclusion of minerals. Analysis of diets confirmed expectations from the experimental design with $\mathrm{CP}$ and $\mathrm{ADF}$ changing as expected with dietary ingredient changes.

For growth performance, when reducing the supplement inclusion rate from the manufacturer recommendation of $20 \%$ to $5 \%$ or just providing a base mix without additional amino acids through added soybean meal, growth performance was reduced. While the rice bran basal diet was deficient in certain amino acids, vitamin and minerals, just including the base mix was not adequate to achieve improved growth performance. The Ca concentration of rice bran is low [13] and amino acids are limited in rice bran [15] and thus when fed alone does not support optimal growth of pigs. A supplement or base mix is ingredients that can contain these in various concentrations in swine diets [16]. The base mix in this study consisted of minor levels of indispensable amino acids lysine, threonine, methionine, and a concentration of calcium, phosphorus, salt, vitamin and trace minerals. Since the RBB2.5 diet provided enough vitamins and minerals for growth, a lack of addition protein or amino acids was the likely reason for the lower performance. This theory would be supported by pigs that were fed the base mix with $5 \%$ added soybean meal had improved performance compared to being only provided the base mix alone.

While a common practice by small swine farms is to reduce the manufacturer 
suggested level of supplement, this practice in our study showed that pigs had reduced performance The reduction in the protein supplement level from 20 to $5 \%$ of the diet lowered the concentration of diet protein, vitamins, and macro and micro mineral concentration and subsequently their daily intake of those nutrients. However, it would be theorized that the reduction in performance was due to the decrease in protein (amino acids), not levels of vitamin and minerals as the diet. Chemical analysis showed the diet CP content was lowered considerably when only $5 \%$ supplement was included, thus an indication of a deficient amino acid diet or an imbalance of amino acids in the remaining ration. This would be supported by Brestenský [17] who showed that feeding pigs a deficient amino acid diet reduced body weight, and lysine intake compared to amino acid sufficient diet for growing pigs.

As previously stated, the inclusion of soybean meal with base mix had similar performance to that of pigs fed the high level of protein supplement. Soybean meal is routinely used as an amino acid source across the world due to its balanced amino acid concentration for swine. According to study of Moon [18] the inclusion of soybean meal and full-fat soybean in diet supported more rapid growth rate and improved feed efficiency compared to feeding pigs with various plant proteins. Also, research has shown that diets containing SBM had greater standardized ileal digestibility (SID) of most indispensable amino acids compared to other protein ingredients [19].

For economics, pigs fed a RBS20 diet had the highest cost per pig which explains why many small swine producers do not feed this diet even though it is the recommend protein supplement level to be used with rice barn as recommended by the manufacturer. Instead farmers often use a practice such as RBS5 which was lower in feed cost, lower in gain value (revenue), but equal in income over fed cost per pig. Thus they can lower feed input cost yet return the same net value to their farm. Interestingly, including only a base mix in a rice bran diet did not improve economic return compared to feeding the low level of supplement. While both contained added vitamins and minerals, additional amino acids where lacking in the RBB2.5 diet to help improve growth rate to generate additional revenue from selling a heavier weight pig. When the base mix was combined with added soybean, pigs had increased feed cost, as expected, compared to base mix addition alone, but they also had higher gain value (revenue) and income over feed cost. Also, providing a high quality, lower cost source of amino acids, vitamins and minerals such as in the RBSBB diet compared to the RBS20 diet, swine producers can decrease their feed input cost with the same pig weight gain resulting in a higher economic return by approximately $\$ 10$ per pig.

\section{Conclusion}

In conclusion, utilization of soybean meal and a base mix in rice bran diets for finishing pigs provides an opportunity for increased economic return for Cambodia pig farmers over current feedings practices. 


\section{Acknowledgements}

This work was funded in whole or part by the United States Agency for International Development (USAID) Bureau for Food Security under Agreements \# AID-EEP-A-00-09-00004 and AID-OAA-L-15-00003 as part of Feed the Future Innovation Lab for Horticulture and Feed the Future Innovation Lab for Livestock Systems.

\section{Conflicts of Interest}

The authors declare no conflicts of interest regarding the publication of this paper.

\section{References}

[1] Food and Agriculture Organization of the United Nation (FAO) (2011) Pigs for Prosperity. Rome. http://www.fao.org/3/i2471e/i2471e00.pdf

[2] Ministry of Agriculture, Forestry and Fisheries (MAFF) (2017) Annual Report for Agriculture Forestry and Fisheries 2016-2017 and Direction 2017-2018. Cambodia, 32-37.

[3] Chittavong, M., Lindberg, J.E. and Jansson, A. (2012) Feeding Regime and Management of Local Lao Pigs in Central Lao PDR. Tropical Animal Health Production, 45, 149-155. https://doi.org/10.1007/s11250-012-0186-1

[4] Shi, C.X., Liu, Z.Y., Shi, M., Li, P., Zeng, Z.K., Liu, L., Huang, C.F., Zhu, Z.P. and Li, D.F. (2015) Prediction of Digestible and Metabolizable Energy Content of Rice Bran Fed to Growing Pigs. Asian-Australasian Journal of Animal Sciences, 28, 654-661. https://doi.org/10.5713/ajas.14.0507

[5] Soren, N.M., Bhar, R., Chhabra, A.K. and Mandal, A.B. (2003) Performance of Crossbred Gilts Fed on Diets with Higher Levels of Fat and Fibre through Addition of Rice Bran. Asian-Australasian Journal of Animal Sciences, 16, 1650-1655. https://doi.org/10.5713/ajas.2003.1650

[6] Phiny, C., Ogle, B., Preston, T.R. and Borin, K. (2008) Growth Performance of Pigs Fed Water Spinach or Water Spinach Mixed with Mulberry Leaves, as Protein Sources in Basal Diets of Cassava Root Meal plus Rice Bran or Sugar Palm Syrup plus Broken Rice. Livestock Research for Rural Development, 20. https://lrrd.cipav.org.co/lrrd20/supplement/phin2.htm

[7] Sokchea, H., Hong, T.T.T., Ngoan, L.D., Phung, L.D. and Borin, K. (2018) Nutritive Value of Fermented Banana Pseudo Stem (Musa spp) and Rice Bran by Saccharomyces cerevisiae. International Journal of Agriculture Innovation and Research, 7 , 2319-1473.

[8] Calvert, C., Parker, K., Parker, J., Sayre, R. and Saunders, R. (1985) Rice Bran in Swine Rations. California Agriculture, 39, 19-20.

[9] Pok, S., Borin, K. and Sovann, S. (2006) Pig Systems in Southeast Asia-The Case of Cambodia. Proceedings of the Regional Workshop, Bangkok, 23-24 November 2006, 34-42.

http://cdn.dairyasia.org/APHCA/dmdocuments/PAP 06 Asia Pig Systems Ws.pd $\underline{\mathrm{f}}$

[10] National Research Council (NRC) (2012) Nutrient Requirements of Swine. 11th Edition, National Academies Press, Washington DC.

[11] González-Vega, J.C., Kim, B.G., Htoo, J.K., Lemme, A. and Stein, H.H. (2011) 
Amino Acid Digestibility in Heated Soybean Meal Fed to Growing Pigs. Journal of Animal Science, 89, 3617-3625. https://doi.org/10.2527/jas.2010-3465

[12] AOAC (1990) Official Methods of Analysis. 15th Edition, Association of Official Analysis Chemists, Arlington.

[13] Stein, H.H., Lagos, L.V. and Casas, G.A. (2016) Nutritional Value of Feed Ingredients of Plant Origin Fed to Pigs. Animal Feed Science and Technology, 218, 33-69. https://doi.org/10.1016/j.anifeedsci.2016.05.003

[14] Thakur, M. and Hurburgh, C.R. (2007) Quality of US Soybean Meal Compared to the Quality of Soybean Meal from Other Origins. Journal of the American Oil Chemists' Society, 84, 835-843. https://doi.org/10.1007/s11746-007-1107-8

[15] Kaufmann, C., Sauer, W.C., Cervantes, M., Zhang, Y., He, J., Rademacher, M. and Htoo, J.K. (2005) Amino Acid and Energy Digestibility in Different Sources of Rice Bran for Growing Pigs. Canadian Journal of Animal Science, 85, 355-363. https://doi.org/10.4141/A04-084

[16] Reese, D.E., DeRouchey, J.M. and Meisinger, D.J. (2010) Methods of Supplying Nutrients to Swine. National Swine Nutrition Guide. U.S. Pork Center of Excellence. Chap. 28, 252-254.

http://porkgateway.org/resource/methods-of-supplying-nutrients-to-swine/

[17] Brestenský, M., Nitrayová, S., Patráš, P. and Heger, J. (2014) Effect of Severe Amino Acid Restriction on Subsequent Growth Performance and Urinary N Excretion in Growing Pigs. Livestock Science, 167, 286-291. https://doi.org/10.1016/j.livsci.2014.07.008

[18] Moon, H.K., Kim, J.W., Heo, K.N., Kim, Y.H., Kim, S.W., Kwon, C.H., Shin, I.S. and Han, I.K. (1994) Growth Performance and Amino Acid Digestibilities Affected by Various Plant Protein Sources in Growing-Finishing Pigs. Asian-Australasian Journal of Animal Sciences, 7, 537-546. https://doi.org/10.5713/ajas.1994.537

[19] Son, A.R., Park, C.S., Park, K.R. and Kim, B.G. (2019) Amino Acid Digestibility in Plant Protein Sources Fed to Growing Pigs. Asian-Australasian Journal of Animal Sciences, 32, 1745-1752. https://doi.org/10.5713/ajas.19.0037 